\title{
INFLUENCE OF MODERN PROCESS PERFORMANCE INDICATORS ON CORPORATE PERFORMANCE - THE EMPIRICAL STUDY
}

\author{
ANDREA SUJOVÁ, KATARÍNA MARCINEKOVÁ, \\ L'UBICA SIMANOVÁ
}

\begin{abstract}
A B S TR A C T
The increasing pressure of globalisation on the worldwide market has forced enterprises to shift their focus from product quality to effectiveness of internal business processes. The object of interest of this paper is a modern management approach based on corporate performance evaluation by measuring the performance of internal processes. The paper aims to prove that the use of modern indicators and the measurement of internal processes belong among factors that have a direct positive impact on corporate performance. To reach the aim, empirical primary research was carried out. The paper focused on research results regarding the use of modern indicators for the measurement of business processes in Slovak industrial enterprises from selected branches. The primary quantitative research was conducted using questionnaires. The research aimed to test the hypothesis stating that enterprises using modern indicators to measure process performance have been reaching more positive ROE values, representing a basic indicator of corporate performance. Dependences among the data selected from the empirical research were analysed using statistical methods, namely, the chi-squared test, T-test and the correlation analysis. Based on the statistically processed data, the authors concluded that business processes are a basic source for the evaluation of corporate performance. Higher ROE values can be reached using modern process indicators, especially in mass production enterprises. The paper contributed to the further development of knowledge in performance management, specifically, process-oriented management.
\end{abstract}

KEY WORDS

corporate performance, process performance measurement, process indicator, industrial enterprises

DOI: 10.2478/emj-2019-0015
Corresponding author:

Andrea Sujová

Mendel University in Brno, Czech Republic e-mail: andrea.sujova@mendelu.cz

Katarína Marcineková

Technical University in Zvolen, Slovakia e-mail: xmarcinekovak@tuzvo.sk

L'ubica Simanová

Technical University in Zvolen, Slovakia e-mail: lubica.simanova@tuzvo.sk

\section{INTRODUCTION}

Corporate performance management presents a way of motivation and management by objectives characterised using quantitative performance indicators. Besides the application of traditional methods in business, successful economic development and market environment development also require the application of new modern methods adapted to con- temporary market needs. One modern approach is based on corporate performance evaluation by measuring the performance of internal processes (Sujová, 2013). Business processes are objects of the process approach to management based on enterprise search and analysis from the point of view of business activities and activities performed by managing staff. The basic idea of the process approach is that low business 
performance is caused by ineffective internal processes which should be changed, aiming to increase efficiency and higher added value for the customer. For many authors, process management is the most substantial breakthrough of the 20th century. Process management presents systems, procedures, methods and tools for sustainable maximised performance and continuous improvement of business processes with the aim to fulfil determined strategic goals.

Business process measurement and valuation are based on the identification of parameters and internal structures in each internal business process, including the most important attributes: the customer, inputs, outputs and process boundaries. Process indicators are known as key performance indicators (KPIs). Determining correct KPIs with an informative value is the most important task in effective measurement and management of business processes and also of corporate performance. KPIs of internal processes should be determined in a way that enables to monitor the fulfilment of corporate key result indicators or strategic key success factors. This is the reason why the literature review of the article focused on this part of the business process measurement.

Modern management approaches require using modern methods and indicators for performance evaluation. The interconnection between process performance measurement and corporate performance evaluation has not been addressed in scientific publications. Most of the scientific works deal with corporate performance or process performance separately. Consequently, the decision was made to undertake research focused on the connection between process measurement by modern indicators and the corporate performance result represented by the return on equity (ROE). According to Evans (2018), ROE reflects operational efficiency, and it is more representative than simple profit indicators (profit before or after tax).

The paper aims to prove that one of the factors influencing corporate performance is its management using modern indicators and measuring internal processes. To reach the aim, empirical primary research was carried out.

The second part of the paper presents the research methodology, which was based on primary quantitative research using questionnaires. The third part details the results of the research, and the last part offers the conclusions and explains the contribution to the development of scientific knowledge.

\section{LITERATURE REVIEW}

Theoretical knowledge concerning process performance indicators was compiled from several sources. Publications dealing with the process performance measurement formed the basis for summarising the recent knowledge on the addressed issue.

It is not enough to control product quality at the end of the manufacturing process, and the performance measurement of the entire manufacturing process alone does not consider the hidden factory. In this sense, the hidden factory means many opportunities for non-conformities to occur before a product is delivered to the customer (Sujová et al., 2016). Six Sigma method measures the ability of an organisation to do things right for the first attempt. An opportunity for a non-conformity is defined from all points of view. In the scope of these facts, process management is in the foreground (Soleimannejad, 2004).

When a company wants to implement process management, first, internal processes and their structure must be identified. According to EN ISO 9001, process is a set of activities, by which inputs are transformed into outputs through the utilisation and managing enterprise sources. A process output has a value for both types of customers: internal and external. Clearly defined indicators, target values and rules of process measurement and evaluation are necessary conditions of a functioning process system (Šmída, 2007).

According to Palmberg (2009), the methodology corresponding to process management as a structured and systematic approach to the analysis and continuous improvement of a process can be summarised as process selection, description and mapping, organising for quality, process measurement and quantification, and process improvement.

The identification of performance measures and targets for process management is the contents of process measurement. This issue has been addressed in scientific works by Melan (1989), Jones (1994), Harrington (1995), Sinclair and Zairi (1995), Armistead et al. (1999), Pritchard and Armistead (1999).

Some discussions about process measurement posed a question regarding the process dimension for measurement and relationships between process performance, effectivity, efficiency, productivity, quality, capability and adaptability. According to Sujová, Marcineková and Hittmar (2017), the pre- 
sumption of effective performance management and sustainable improvement are the measurement, assessment, control, and further optimisation of the internal processes.

According to Rongier (2010), process performance improvement requires to measure two categories of indicators: process efficiency (doing the right things) and process effectiveness (doing things right). According to Oak Ridge Institute for Science and Education (2014), performance measures can be grouped into six categories: process efficiency, effectiveness and:

- Quality as the level of meeting customer needs, requirements and expectations.

- Timeliness, which uses a determined criterion, usually based on customer requirements, to measure whether a work unit was done correctly and on time.

- Productivity as an added value of the process divided by the value of labour and capital consumption.

- Safety, which measures the overall health of the organisation and the working environment of its employees.

One of the most difficult tasks of process measurement is to propose suitable indicators. Process indicators could be divided based on various factors. Differences exist between indicators for production and non-productive processes. According to Parmenter (2007), there are three types of process performance measures:

- Key results indicators (KRIs) measure results of many actions and focus on a long period (customer and employee satisfaction, net profit before tax...).

- Key performance indicators (KPI's) are the most critical for the current and future success of an enterprise. Parmenter defines seven characteristics of KPI's: not expressed in financial statements, often measured, affecting the CEO and the senior management team, understood by all staff and requiring corrective actions, having a substantial impact on the most of critical success factors, having a positive impact on all other performance measures.

- Performance indicators (PIs) lie between KPIs and KRIs and are shown in the scorecard with KPIs (profit received from the top 10\% of the customers, net profit on key product lines...).

Performance requirements for business processes can be specified using process performance indicators (PPIs) with determined target values. A PPI is a kind of key performance indicator (KPI) that focuses exclusively on the indicators defined for business processes. Consequently, it is suitable to integrate the management of PPIs into the whole business process lifecycle from its design to its evaluation (Ortega et al., 2010).

To define PPIs in a way that is unambiguous and highly expressive, understandable by technical and non-technical users and traceable in a business process, PPINOT metamodel can be used as proposed by Ortega et al. (2013), which is independent of the process modelling language.

Gradišar et al. (2008) put forward an approach to measuring and presenting the achieved production objectives in the form of production KPIs and proposed to incorporate KPIs into a closed-loop production control system. To control the production process, it is necessary to measure productivity, product quality and production cost. Productivity is defined as the amount of all products that were manufactured in a certain production period and could be calculated. The mean product quality is the mean value of quality factors of the batches produced in the defined period. To calculate the mean production cost, it is important to sum up variable and fixed costs, and to calculate them for a unit of the final product. Vukomanovič et al. (2010) defined KPIs as indicative performance measures that assess unfinished processes. KPIs are not in direct correlation with, for example, cost but are indirect factors, such as communication and motivation, and lead to the results.

The Activity Based Costing is a method of calculating process costs. First, the activities are identified, and then costs are assigned to activities (based on the use of resources), and finally, costs are allocated to products according to the ratio of activity production (Remeň \& Sujová, 2018).

In the scientific paper by Milanović (2011), the most important individual performance measures are divided into four categories: Quality, Time, Flexibility and Costs.

In a case study, Senvar et al. (2014) analysed eight process performance indicators considered to be appropriate for all processes: inventory waiting time, profit/cost of product sale, customer continuity, scrap/sales percentage, change in customer complaints, total performance of suppliers, capacity and research, and development investments per employee.

Agarwal et al. (2007) addressed indicators of process adaptability. Among the most important indicators of process agility belong market sensitive- 
ness, delivery speed, data transfer speed, lead time reduction, service level improvement, cost and uncertainty minimisation, customer satisfaction, quality improvement, trust development, and change resistance minimisation.

One strategic performance management system that uses process principles is a Balanced Scorecard (BSC) developed by Kaplan and Norton (2000). It is a system that divides indicators into four dimensions: the financial perspective, the customer perspective, the perspective of internal processes, and the perspective of learning and growth. The integration of financial performance into the BSC model can be provided through the Creditworthy Model of Performance (Kiselakova et al., 2018). The BSC concept is used mostly in industrial enterprises that use nonfinancial indicators besides financial in management (Dobrovič et al., 2018).

The Holistic Process Performance Measurement System requires the relevant data of performance from various operational information systems, such as workflow systems or ERP systems. It is the approach of extracting data from different operational IT systems (Kueng, 2001): personal data from human resources, sale data from customer orders, clickstream data from the web server and market research data from the external database. According to this idea, the performance measurement system (PMS) is designed based on the business process at the scale of an enterprise. The SCOR model, developed by the Supply Chain Council and seventy world's leading companies, provides a unified representation of supply chains with five general processes: Plan, Source, Make, Deliver and Return (Hudson, 2001).

The corporate performance can be evaluated by a systematic decision-making procedure that combines selected multiple-attribute decision-making (MADM) methods combined with the analytic hierarchy process (AHP). AHP is applied to facilitate group decision making among managers and to set their priorities for further performance evaluation (Franek \& Kashi, 2017).

The theoretical knowledge study led to the following typology of process indicators:

- Universal process indicators have a universal character and can be used by different measurements. They are usually connected with such categories as time, flexibility, environmental impact and costs.

- Indicators for the measurement of production processes are indicators needed for operative production management, such as labour produc- tivity, capital productivity, total effectivity of equipment, fulfilling the standards of machines and workers, material turnaround, the rate of working hours to performance.

- Indicators for the measurement of non-production processes. Non-production processes are all processes running before the production (product development and innovation, marketing process), during the production (machine maintenance and repair) and after the production (service, sale).

The enterprises use many indicators, so it is necessary to create a system for preserving functionality and clarity. It is essential to connect corporate performance management and process performance. It can be achieved by the integration of process performance indicators into corporate KPIs.

What process indicators are suitable? What indicators are used in companies achieving the highest performance results? Has a modern approach to performance measurement impacts on performance results? As these research questions were deemed important, an empirical research was undertaken to test the following hypothesis: Enterprises that use modern indicators for process performance measurement have been reaching more positive ROE values.

\section{RESEARCH METHODS}

A questionnaire was used for primary quantitative research to analyse the current performance management situation in Slovak enterprises. The research objective was to analyse the use of traditional and modern methods and tools for process performance management and measurement in Slovak enterprises from selected industrial branches. In the first step, the database of enterprises was created. The information sources mostly came from the Internet databases and the Slovak Statistical Bureau. The database comprised 2235 enterprises from branches of engineering, construction, automotive and woodprocessing industries. Internet applications were used to develop the online questionnaire and distribute it to the enterprises. Data collection and the creation of the on-line database were undertaken in the first quarter of 2018. In total, 164 filled questionnaires were returned, which comprised a representative research sample.

Questionnaire questions were divided into three areas: common characteristics (branch, region, ownership, number of employees, activity orientation, 
type of production organization), financial results (turnover, indicator ROE) and the area of internal processes. Questions concerning indicators for process measurement were as follow:

- What indicators for the measurement of production process performance are used in your company?

- What indicators for the evaluation of employee performance in processes are used in your company?

- What internal processes and their indicators are regularly measured and evaluated in your company?

An integral part of the research objective was testing the main hypothesis, stating that enterprises that use modern indicators for process performance measurement have been reaching more positive ROE values.

In addition, two more hypotheses were tested:

- The use of modern employee performance indicators does not depend on the reached $\mathrm{ROE}$ value.

- Regular measurement of internal processes does not depend on the reached higher ROE value.

The acquired data was statistically evaluated. The acceptable margin of error (the confidence interval) was set to $\pm 10 \%$. The proportion of characteristic is unknown, so the probability of characteristic occurrence was $50 \%$. The confidence level was $95 \%$. Statistical formulas were used for counting the sample size using an Internet application "Sample Size Calculation", and the result was 97 .

Dependences among the selected data were analysed using chosen statistical methods: the chi-squared test, T-test and the correlation analysis. First, pivot tables were created. The next step was to count the expected frequencies and compare them with observed frequencies.

Chi-squared test or $\chi^{2}$ test is a statistical test commonly used to compare observed data with data expected to obtain according to a specific hypothesis. The Pearson's chi-squared test as a test of independence assesses whether paired observations of two variables are independent of each other. The chisquared statistic can then be used to calculate a p-value by comparing the value of the statistic to a chi-squared distribution.

The T-test is a statistical hypothesis test in which the test statistic follows a Student's distribution if the null hypothesis is supported. It can be used to determine if two sets of data are significantly different from each other (Shuttleworth, 2008).
The strength of the mutual dependence between selected relations was analysed using the correlation analysis. The statistical correlation is a statistical technique which shows whether two variables are related. It is measured by the coefficient of correlation $(\mathrm{r})$. Its numerical value ranges from +1.0 to -1.0 . It indicates the strength of a relationship. The closer the coefficients are to +1.0 and -1.0 , the greater is the strength of the relationship between the variables (Rubin, 2010, s. 136-137). The formula for calculating the correlation coefficient $(r)$ is:

$$
\operatorname{Correl}(X, Y)=r=\frac{\sum(x-\bar{x})(y-\bar{y})}{\sqrt{\sum(x-\bar{x})^{2} \sum(y-\bar{y})^{2}}}
$$

\section{DISCUSSION OF RESEARCH RESULTS}

Once the theoretical knowledge was studied to test the research hypothesis, process indicators were divided into two groups:

- traditional process indicators based on process costs, quality and time measurement,

- modern process indicators based mostly on process productivity, efficiency and value-added measurement.

This part of the paper shows the selected research results that present the impact made by the use of modern process indicators on corporate performance of Slovak enterprises and enable the verification of the stated hypothesis by showing the existence of connections between effective process performance measurement and the reached ROE value as a representative indicator of corporate performance.

The paper presents the results of the statistical CHI-square test, T-tests and the correlation analysis between used process indicators, the number of regularly measured processes and the reached ROE value. Results of the descriptive statistic concerning ROE are presented in Tab. 1. Kurtosis of the set data was

Tab. 1. Descriptive statistics ROE

\begin{tabular}{|l|r|l|r|}
\hline Mean & 3.385714286 & Kurtosis & -0.26829549 \\
\hline $\begin{array}{l}\text { Standard } \\
\text { Error }\end{array}$ & 0.391195286 & Skewness & 0.832625377 \\
\hline Median & 3 & Range & 13 \\
\hline Mode & 1 & Minimum & -1.5 \\
\hline $\begin{array}{l}\text { Standard } \\
\text { Deviation }\end{array}$ & 4,008558838 & Maximum & 11.5 \\
\hline $\begin{array}{l}\text { Sample } \\
\text { Variance }\end{array}$ & 16.06854396 & Sum & 355.5 \\
\hline
\end{tabular}




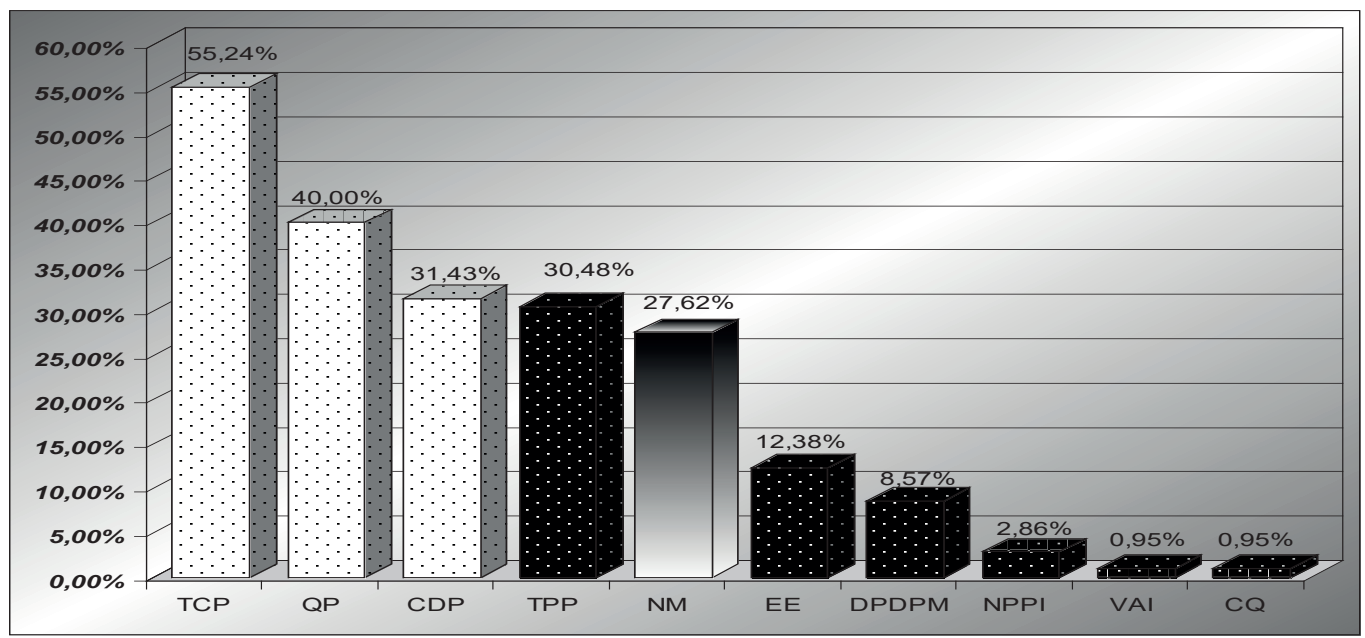

Legend:

Traditional indicators Total cost of the process (TPC),

Quality of the process (QP)

Continual duration of the process (CDP)

Modern indicators Total productivity of the process (TPP),

Efficiency of the equipment (EE)

Duration of product development and placement on the market (DPDPN Number of product and process innovation in a defined period (NPPI)

Process value-added index (VAI), Customer quality (CQ)

$\square_{\text {Not measured }}$

Not used any process performance indicator (NM)

Fig. 1. Used process indicators

negative; it means that the distribution of the data was relatively flat in comparison with the normal distribution. The positive skewness means that the distribution was asymmetric, and most of the data were smaller than the mean value.

Results of primary quantitative research that are partly related to the use of process indicators are shown in Fig. 1. According to the figure, $28 \%$ of monitored enterprises do not use any modern process indicator. An enterprise uses 1.83 indicators on average (modern or traditional). Approximately $41 \%$ of the sample use one or more than one modern indicators. $46.5 \%$ of those enterprises have only domestic capital, and 9.3\% have mainly domestic capital.

The dependence between the use of modern process indicators and the reached ROE value was confirmed by the CHI-square test, T-test and the correlation coefficient:

- $\chi^{2}=0.05$, which means that the statistically significant dependence exists between variables. Additionally, the researched sample was divided into two parts: enterprises with small-lot production or job-work and enterprises with mass production. CHI-Square Tests were made for these parts. The P-value for the first group was calculated $=0.59$, so no statistically significant dependence exists between the variables. On the other hand, in the second part, the P-value was 0.04 , so statistically significant dependence exists between variables.

- The T-test showed that T Stat is higher than $\mathrm{t}$ Critical for one tail test. It means that enterprises using modern process indicators reach a higher ROE level. Results are shown in Tab. 2.

- The correlation coefficient: $r=0.586$ means strong positive dependence between the variables.

Fig. 2 presents a bar chart showing the percentage of the use of employee performance indicators in the researched sample. The research results given in Fig. 2 indicate that $10.48 \%$ of the sample use no employee performance indicators. An enterprise used 2.18 indicators on average. The most widely used modern indicator was VAE (employee value added). A third of the sample used one or more modern indicators. This part of the sample used 44 modern indicators and 64 traditional indicators. 
Tab. 2. T-test: two-sample assuming equal variances

\begin{tabular}{|l|r|r|}
\hline \multirow{2}{*}{ ROE } & \multicolumn{2}{|c|}{ MODERN INDICATORS USING } \\
\cline { 2 - 3 } & \multicolumn{1}{|c|}{ YES } & \multicolumn{1}{c|}{ No } \\
\hline Mean & 3.885714286 & 2.385714286 \\
\hline Variance & 17.51573499 & 12.06008403 \\
\hline Observations & 70 & \\
\hline Pooled Variance & 15.7148405 & \\
\hline $\begin{array}{l}\text { Hypothesized Mean } \\
\text { Difference }\end{array}$ & 103 & \\
\hline df & 1.827783123 & \\
\hline $\mathrm{t}$ Stat & 0.035238462 & \\
\hline $\mathrm{P}(\mathrm{T}<=\mathrm{t})$ one-tail & 1.659782274 & \\
\hline $\mathrm{t}$ Critical one-tail & & \\
\hline
\end{tabular}

To verify the main research hypothesis, a CHIsquare test was used. Both hypotheses were defined. $\mathrm{H} 0$ : The use of modern employee performance indicators does not depend on the reached ROE value; and Ha: The use of modern employee performance indicators depends on the reached ROE value. The calculated p-value was under the 0.05 (actually, 0.01787 ), so the null hypothesis was rejected. In other words, there was a statistically significant relevance between the use of modern employee performance indicators and the reached ROE value.
The strength of dependence between monitored variables was found using the correlation coefficient. The strongest relationship was found between the reached ROE value and the number of used indicators for employee performance measurement. The reached correlation coefficient of 0.579 means a strong dependence, only $33.49 \%$ of the ROE value variability depended on the number of used indicators.

The following bar chart (Fig. 3) shows internal processes that were mostly measured by Slovak enterprises. Research results presented in Fig. 3 showed that enterprises mostly measured the production process. $9.52 \%$ of the sample did not measure any process, $85.7 \%$ measured the main processes, $62.9 \%$ measured the support processes and 30.5\% measured the managerial processes. An enterprise measured 3.25 processes on average.

In the next step, the CHI-square tests have been used. The research sample was divided into two groups according to the reached level of return on equity (ROE $<4 \%$ and $\mathrm{ROE}>4 \%$ ). The null hypothesis stated that Regular measurement of internal processes does not depend on the reached higher ROE value. According to Tab. 3, the null hypotheses were rejected in two cases. A statistically significant

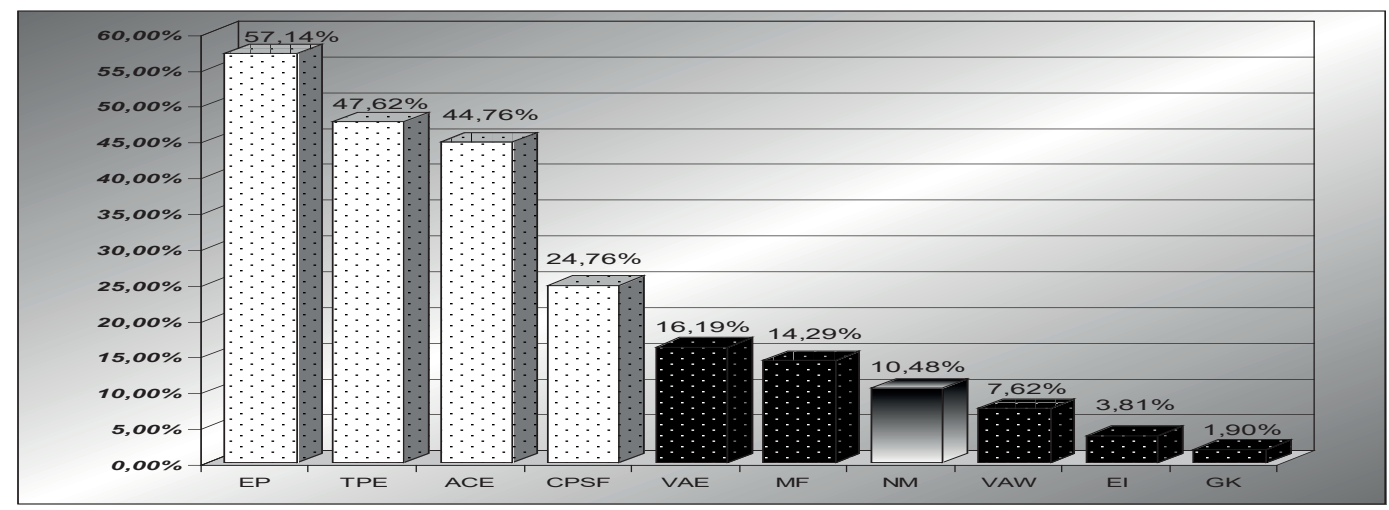

Legend:

Traditional indicators

Modern indicators

Not measured

Fig. 2. Used employee performance indicators
Employee productivity (EP)

Total performance per employee (TPE)

Averaged costs per employee (ACE)

Coefficient of performance standards fulfilment (CPSF)

Employee value added (VAE)

Motivational factors (MF)

Wages value added (VAW)

Number of employee innovation (EI)

Amount of given knowledge per defined period (GK)

Not used any employee performance indicator (NM) 


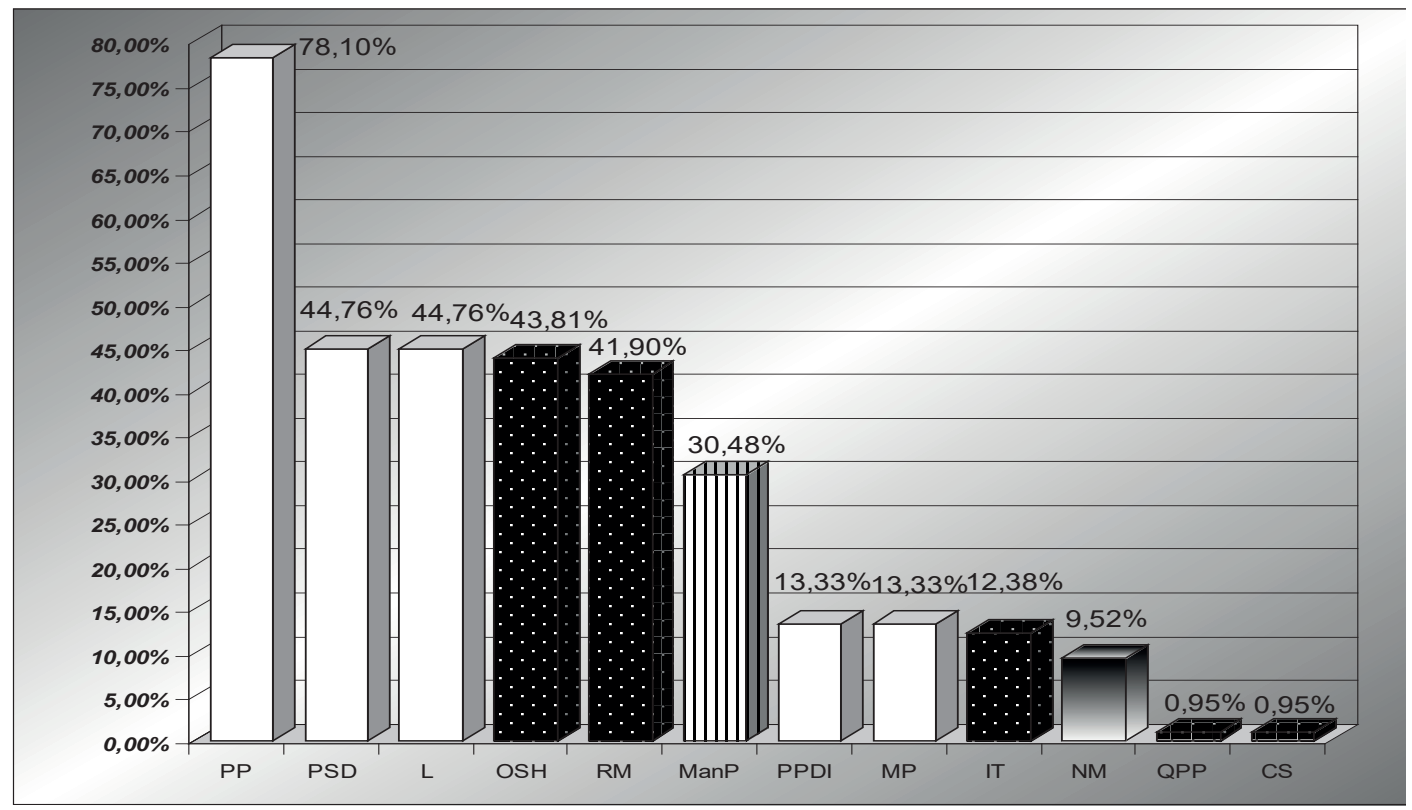

Legend:
$\mathbb{W}_{\text {Managerial processes }}$
$\boldsymbol{\square}_{\text {Not measured }}$

Main processes

Support processes

Managerial processes
$\square_{\text {Not measured }}$

Production process (PP)

Process of sale and delivery (PSD)

Logistics (L)

Process of new product development and innovation (PPDI)

Marketing processes (MP)

$\mathrm{OSH}$ and fire protection (OSH)

Repair and maintenance (RP)

Information systems and IT support (IT)

The quality of production process for manufacturing workers (QPP. Customer satisfaction (CS)

(ManP)

Not measured any process (NM)

Fig. 3. Regularly measured processes

Tab. 3. ROE and regularly measured processes

\begin{tabular}{|l|r|r|r|}
\hline & \multicolumn{1}{|c|}{$\begin{array}{c}\text { MAIN } \\
\text { PROCESSES }\end{array}$} & \multicolumn{1}{c|}{$\begin{array}{c}\text { MANAGERIAL } \\
\text { PROCESSES }\end{array}$} & $\begin{array}{c}\text { SUPPORT } \\
\text { PROCESSES }\end{array}$ \\
\hline $\mathrm{p}$-value & 0.02151 & 0.01063 & 0.78615 \\
\hline $\mathrm{H}_{0}$ & Rejected & Rejected & Fail to reject \\
\hline
\end{tabular}

dependence was found between the degree of return on equity and the measurement of the main processes and managerial processes.

Furthermore, the influence of the qualitative level of process implementation on ROE was tested. The data was used for the CHI-square test and the $\mathrm{P}$ - value was $=0.002$. Statistically significant depen- dence was found between the level of process management and the level of ROE.

As for the correlation analysis, a strong relationship was found between the qualitative level of process implementation and the reached ROE value. The correlation coefficient of this relationship was high $(\mathrm{r}=0.626)$.

In addition, the T-test for two samples was used (Tab. 4). Data in Tab. 4 showed that T Stat was higher than $\mathrm{t}$ Critical for one tail test ( $\mathrm{p}$-value $=0.02$ ), and also for two tail test ( $\mathrm{p}$-value $=0.03$ ). It means that the influence of the level of process implementation on the reached ROE was statistically significant with the 
Tab. 4. T-test: two-sample assuming equal variances

\begin{tabular}{|l|r|r|}
\hline \multirow{2}{*}{\multicolumn{1}{|c|}{ ROE }} & \multicolumn{2}{|c|}{ Process IMPLEMENTATION } \\
\cline { 2 - 3 } & \multicolumn{1}{|c|}{ HIGH LeVEL } & \multicolumn{1}{c|}{ LOW LEVEL } \\
\hline Mean & 4.185185185 & 2.539215686 \\
\hline Variance & 18.39902166 & 12.49843137 \\
\hline Observations & 54 & \\
\hline Pooled Variance & 15.53465744 & \\
\hline $\begin{array}{l}\text { Hypothesized } \\
\text { Mean Difference }\end{array}$ & 0 & \\
\hline df & 103 & \\
\hline $\mathrm{t}$ Stat & 2.138741325 & \\
\hline $\mathrm{P}(\mathrm{T}<=\mathrm{t})$ one-tail & 0.017410201 & \\
\hline $\mathrm{t}$ Critical one-tail & 1.659782274 & \\
\hline $\mathrm{P}(\mathrm{T}<=\mathrm{t})$ two-tail & 0.034820403 & \\
\hline $\mathrm{t}$ Critical two-tail & 1.98326409 & \\
\hline
\end{tabular}

probability of 95\%. Enterprises with higher levels of process implementation had $4.19 \%$ of ROE on average, and enterprises with lower levels of process implementation had $2.54 \%$ of ROE on average. The difference was statistically significant.

\section{DISCUSSION}

The research findings have shown that enterprises with higher corporate performance results used modern indicators for process measurement, such as the total process productivity, the efficiency of equipment and process innovations. These indicators correspond with Rongier (2010), who pointed to the necessity to measure process efficiency by process improvement. Most of the researched enterprises used indicators for costs, quality and the duration of the process, which was also defined by the Oak Ridge Institute for Science and Education Performance (2014) and by Milanović (2011).

As for employee performance indicators, the research showed that productivity, cost and the total performance of employees were monitored the most. However, enterprises with higher performance results used indicators based on added value and innovations or knowledge transfer. The study by Ortega et al. (2010) confirmed that the mentioned indicators were suitable for the integration into the whole corporate lifecycle and corporate KPIs, according to Parmenter (2007).

According to the research findings, the mostly measured processes were the main processes, namely, production and supply and sale, but not marketing and innovation processes. In the group of supported processes, the satisfaction of customers and employees with the quality was monitored the least. However, according to Rongier (2010) and Senvar et al. (2014), it is very important when an enterprise wants to improve its performance.

The research also confirmed that enterprises with a higher level of process management reach higher performance. This result supports the findings of previous research carried out by different authors (Marcineková \& Sujová, 2015). The results presented in the paper also extended the findings by Sujová and Marcineková (2015), which proved that modern methods of process management have a positive impact on corporate performance.

\section{CONCLUSIONS}

The results of primary quantitative research in Slovak industrial enterprises confirmed the hypothesis stating that enterprises using modern indicators for business process measurement reached the best corporate performance results represented by return on equity (ROE). The most used process indicators in Slovak manufacturing companies were traditional: process costs, quality and duration. The used modern indicators were the total process productivity and equipment efficiency. On the other hand, more than $27 \%$ of enterprises did not measure internal processes.

Higher ROE values can be reached using modern process indicators, especially in mass production enterprises. Modern process and employee performance indicators are based on traditional indicators but mostly differ by future orientation. Using this type of indicators, firms become more competitive. In particular, the results of the CHI-square test and the correlation analysis showed the existence of a high dependence between return on equity (business performance indicator) and process (main and managerial) monitoring. Moreover, the relevance between the level of process management implementation and the reached ROE level was statistically confirmed. Enterprises, having implemented internal processes at a higher qualitative level, had higher ROE values.

Therefore, it can be stated that aiming to achieve higher corporate performance Slovak enterprises should pay attention to the measurement of internal processes using modern indicators. Slovak enterprises should increasingly focus on regular evaluation 
and improvement of innovation processes and marketing process.

The mentioned findings allow concluding that business processes are a basic source of corporate performance evaluation. It is important to know which process improvement has the greatest impact on the total performance so that manager could focus on critical (key) areas.

\section{ACKNOWLEDGEMENT}

Authors are grateful for the support of the National Agency for Agricultural Research, Grant No. QK1820358.

\section{LITERATURE}

Agarwal, A., Shankar, R., \& Tiwari, M. K. (2007). Modeling agility of supply chain. Industrial Marketing Management, 36, 443-457. doi:10.1016/j.indmarman.2005.12.004

Armistead, C., \& Machin, S. (1997). Implications of business process management for operations management. International Journal of Operations \& Production Management, 17(9), 886-98.

Development Processes (2014). Performance Measurement Process. Oak Ridge Institute for Science and Education.

Dobrovič, J. et al. (2018). Balanced Scorecard concept as a tool of strategic management and its usage in the construction industry. Polish Journal of Management Studies, 18(2), 59-72. doi: 10.17512/ pjms.2018.18.2.05

Evans, O. (2018). Improved financial performance without improved operational efficiency: the case of Nigerian firms. Forum Scientiae Oeconomia, 6(3), 25-39. doi: 10.23762/FSO_VOL6_NO3_2

Franek, J., \& Kashi, K. (2017). Application of hybrid madm methods for performance evaluation in manufacturing. Forum Scientiae Oeconomia, 5(2), 41-54. doi: 10.23762/fso_vol5no2_17_4

Gradišar et al. (2008). Model - based Production Control. Journal for Control, Measurement, Electronics, Computing and Communications, 49(3-4).

Harrington, H. (1995). Total Improvement Management The Next Generation in Performance Improvement. New York, United States: McGraw-Hill.

Hudson et al. (2001). Theory and Practice in SME Performance Measurement Systems. International Journal of Operations \& Production Management, 21(8), 1096-1115.

Jones, C. (1994). Improving your key business processes. The TQM Magazine, 6(2), 25-29.

Kaplan, R. S., \& Norton, D. P. (2000). The Balanced Scorecard. Praha, Czech Republic: Grada Publishing.
Kiseláková, D. et al. (2018). Analysis of enterprise performance and competitiveness to streamline managerial decisions. Polish Journal of Management Studies, 17(2), 101-111. doi: 10.17512/pjms.2018.17.2.09

Kueng, P. et al. (2001). A Holistic Process Performance Analysis through a Performance Data Warehouse. Proceedings of the American Conference on Information Systems, Boston, USA.

Marcinekova, K., \& Sujova, A., (2015). The influence of the process control level on the enterprises' ROE. Procedia Economics and Finance, 34, 290-295. doi: 10.1016/S2212-5671(15)01632-9

Melan, E. (1989). Process management: a unifying framework for improvement. National Productivity Review, 8(4), 395-406.

Milanović Glavan, Lj. (2011). Understanding Process Performance Measurement System. Business System Research, 2(2), 1-56.

Ortega, A., Resinas, M., \& Ruiz-Cort'es, A. (2010). Defining Process Performance Indicators: An Ontological Approach. In Meersman, R. et al. (Eds.), OTM, Part I, LNCS 6426 (pp. 555-572). Berlin, Heidelberg, Germany: Springer-Verlag.

Ortega, A., Resinas, M., Cabanillas, C., \& Ruiz-Cort'es, A. (2013). On the definition and design-time analysis of process performance indicators. Information Systems, 38, 470-490. doi: 10.1016/j.is.2012.11.004

Palmberg, K. (2009). Exploring process management: are there any widespread models and definitions? The TQM Journal, 21(2), 203-215. doi: $10.1108 / 17542730910938182$

Parmenter, D. (2007). Key performance indicators. 1st. ed. New Jersey, United States: John Wiley \& Sons.

Pritchard, J., \& Armistead, C. (1999). Business process management: lessons from European business. Business Process Management Journal, 5(1), 10-32.

Remeň, O., \& Sujová, A. (2018). Management of changes in business processes: an empirical study in Slovak enterprises, Engineering Management in Production and Services, 10(3), 37-50. doi: 10.2478/emj-20180015

Rongier et al. (2010). Towards performance measurement system to Control Disastre Response. Collaborative Networks for Sustainable World. Berlin, Heidelberg, Germany: Springer.

Rubin, A. (2010). Statistic for Evidence-Based Practice and Evaluation. 2nd Edition. Belmont, United States: Brooks/Cole.

Senvar et al. (2014). Prioritization of balanced scorecard measurement indicators as a process management approach via fuzzy AHP: case study in automotive industry. Technical Gazette, 21(1), 155-162.

Shuttleworth, M. (2008). Student's T-Test. Retrieved from https://explorable.com/students-t-test

Sinclair, D., \& Zairi, M. (1995). Effective process management through performance measurement, Part III: an integrated model of total quality-based performance measurement. Business Process Re-engineering and Management Journal, 1(3), 50-65.

Šmída, F. (2007). Zavádění a rozvoj procesního řízení ve firmě. Praha, Czech Republic: Grada Publishing. 
Soleimannejad, F. (2004). Six Sigma, Basic Steps \& Implementation. Bloomington, United States: AuthorHouse.

Sujova, A. (2013). Business Process Performance Management - a Modern Approach to Corporate Performance Management. Liberec Economic Forum. Liberec, Czech Republic: TU Liberec.

Sujova, A., \& Marcinekova, K. (2015). Modern Methods of Process Management Used in Slovak Enterprises. Procedia Economics and Finance, 23, 889-893. doi: 10.1016/S2212-5671(15)00381-0

Sujova, A., Marcinekova, K., \& Hittmar, S. (2017). Sustainable Optimization of Manufacturing Process Effectiveness in Furniture Production. Sustainability, 9(6), 923. doi:10.3390/su9060923

Sujová, A., Simanová, L., \& Marcineková, K. (2016). Sustainable Process Performance by Application of Six Sigma Concepts: The Research Study of Two Industrial Cases. Sustainability, 8(3), 260. doi: 10.3390/ su8030260

Vukomanovič et al. (2010). Leading, lagging and perceptive performance measures in the construction industry. Construction: An International Journal, 2(1), 103 111. 